\title{
Antibody levels in human sera measured by the fluorescent-antibody technique against the coxsackie B viruses types 1-5 grown in HEp2 cells compared with results obtained by neutralization
}

\author{
KATHLEEN M. MacWILliam AND MARGARET A. COOPER \\ From the Department of Virology, St Mary's Hospital Medical School, London
}

SYNOPSIS Twenty pairs of acute and convalescent sera were tested for antibody to the coxsackie B viruses types $1-5$ by neutralization and fluorescent-antibody techniques. Results by fluorescence were difficult to read and sensitivity was therefore reduced. Rises by neutralization were type specific in the majority of cases, while those by fluorescence were always against more than one viral type.

Laboratory diagnosis of infection due to enteroviruses is tedious, time consuming and often inconclusive. This is particularly true of methods used for antibody estimations. Other workers (French, Schmidt, Emmons, and Lennette, 1972; Shaw and Newton, Pavell, and Friday 1961; Riggs and Brown, 1962) have used fluorescent antibody techniques for typing enteroviruses, and Riggs and Brown suggested that the technique might be of use for estimating antibody levels. The following short study was therefore carried out to see whether estimation of antibody levels against the coxsackie B viruses by the fluorescent-antibody technique offers any advantage over the neutralization test which is the one most commonly used at present.

Antibody levels were estimated against the coxsackie $B$ viruses types $1-5$ on 20 pairs of acute and convalescent sera by fluorescence and by neutralization. Type 6 was not included in the results because it was not neutralized by any of the 20 pairs of sera.

\section{Methods}

GROWTH OF HEp 2 CELLS

HEp2 cells were grown in MEM, 0.13 sodium bicarbonate, $10 \%$ calf serum, and 0.002 molar glutamine. Confluent monolayers were taken off $12 \mathrm{oz}$ bottles with a mixture of equal parts of $0.02 \%$ versene and $0.25 \%$ trypsin, the cells were resuspended in growth medium containing $10 \%$ fetal calf serum instead of calf serum, and 0.013

Received for publication 12 June 1974. molar Hepes buffer and the suspension was used for growth on coverslips or for the neutralization tests.

FLUORESCENT-ANTIBODY TECHNIQUE

The cell suspension at a concentration of approximately $200000 / \mathrm{ml}$ was mixed with a suitable concentration of virus and $1.5 \mathrm{ml}$ per compartment was added to sterile multicompartmented polystyrene boxes (Sterilin) each compartment of which contained a $16 \mathrm{~mm} \times 16 \mathrm{~mm}$ coverslip. After a suitable incubation period established by trial and error and dependent on the strength of virus, the coverslips were removed, fixed in acetone for 10 minutes, dried, and frozen at $-20^{\circ} \mathrm{C}$ or less for use for fluorescence.

The coverslips were divided into four using glyceel (Solmedia), and four-fold dilutions of serum under test were added. The preparations were incubated at $36^{\circ} \mathrm{C}$ for 30 minutes and washed well in three changes of phosphate-buffered saline at a pH of 7.3. They were then treated with fluorescein-conjugated antihuman globulin of suitable dilution mixed with an equal volume of $0.2 \%$ naphthalene black, incubated and washed as before, and mounted in $70 \%$ glycerol. They were read using the $\times 40$ objective and the $\times 8$ eyepiece of a Gillett and Sibert conference microscope fitted with a dark ground condenser, Turner filter, and suitable secondary filter.

It was found, even using four-fold dilutions of serum, that the endpoint was gradual and coupled with the subjective nature of the test was difficult to assess. It was taken as the highest dilution giving definite fluorescence, and significant rises were 
considered to be those that had a 16-fold $(2 \times$ fourfold dilutions) or more difference between the acute and convalescent sera.

During preliminary studies, false negative results were obtained because the fluorescence was confined to a few localized patches of cell sheet in spite of a large inoculum. It was also possible for the cytopathic effect to be complete in these localized patches (and therefore not visible by fluorescence) before the surrounding cell sheet was affected. This difficulty was ended when a fixed dose of virus was put with the cell suspension onto the coverslip, and the coverslip was fixed after a predetermined interval.

\section{NEUTRALIZATION TESTS}

This was a modification of the microneutralization test of Kriel, Wulff, and Chin (1969). Microtitre equipment consisting of disposable tissue culture flat-bottomed plates with rigid lids, $50 \mu 1$ dropping pipettes, and $50 \mu \mathrm{l}$ microdiluters were used. All dilutions were made in growth medium consisting of MEM, $0 \cdot 13 \%$ sodium bicarbonate, $10 \%$ fetal calf serum, 0.002 molar glutamine, and 0.013 molar Hepes buffer.

Fifty $\mu \mathrm{l}$ of virus containing 33 to $1000 \mathrm{TCD}_{50}$ was added to $50 \mu \mathrm{l}$ of serum dilution in each well. Fifty $\mu \mathrm{l}$ of cell suspension containing approximately 10000 cells in growth medium was added to the serum virus mixture.

Lids were put on the plates, and the plates in sealed sandwich boxes were incubated at $36^{\circ} \mathrm{C}$ for $\mathrm{c}$ five days.

The titre of serum was taken as the last hole showing complete inhibition of viral growth. Fourfold rises were considered significant.

\section{Results}

Serum titres by fluorescence and neutralization $\infty$ against the coxsackie $B$ viruses types 1-5 on $20 \mathrm{G}$ paired acute and convalescent sera are shown in the 윽 table.

\begin{tabular}{|c|c|c|c|c|c|c|c|c|c|c|c|}
\hline \multirow{2}{*}{$\begin{array}{l}\text { Patient } \\
\text { No. }\end{array}$} & \multirow[t]{2}{*}{ Serum } & \multicolumn{5}{|c|}{ Fluorescence } & \multicolumn{5}{|c|}{ Neutralization } \\
\hline & & $B_{1}$ & $B_{2}$ & $B_{3}$ & $B_{4}$ & $B_{5}$ & $B_{1}$ & $B_{2}$ & $B_{3}$ & $B_{4}$ & $B_{5}$ \\
\hline \multirow[t]{2}{*}{1} & Acute & 32 & 32 & 32 & 32 & 32 & $<16$ & $<16$ & $<16$ & $<16$ & $<16$ \\
\hline & Convalescent & 512 & 128 & 512 & 512 & 512 & $>256$ & $<16$ & $<16$ & $>256$ & $<16$ \\
\hline \multirow[t]{2}{*}{2} & Acute & 32 & 8 & 8 & 8 & 8 & $<4$ & $<4$ & $<4$ & $<4$ & $<4$ \\
\hline & Convalescent & 128 & 128 & 128 & 128 & 128 & 16 & $<4$ & $<4$ & $<4$ & $<4$ \\
\hline \multirow[t]{2}{*}{3} & Acute & $<8$ & $<8$ & $<8$ & $<8$ & $<8$ & $<16$ & $<16$ & $<16$ & $<16$ & $<16$ \\
\hline & Convalescent & 512 & 512 & 512 & 512 & 512 & $<16$ & $<16$ & $<16$ & 512 & $<16$ \\
\hline \multirow[t]{2}{*}{4} & Acute & 32 & 8 & 8 & 32 & 32 & $<16$ & $<16$ & 32 & $<16$ & $<16$ \\
\hline & Convalescent & 512 & 32 & 512 & 512 & 128 & 32 & $<16$ & 256 & 128 & $<16$ \\
\hline \multirow[t]{2}{*}{5} & Acute & 512 & 128 & 32 & 128 & 32 & $<16$ & $<16$ & 32 & 64 & $<16$ \\
\hline & Convalescent & 512 & 512 & 512 & 512 & 512 & $<16$ & $<16$ & 64 & 256 & $<16$ \\
\hline \multirow[t]{2}{*}{6} & Acute & 128 & 128 & 128 & 128 & 128 & $<16$ & 64 & $<16$ & 16 & 32 \\
\hline & Convalescent & 512 & 128 & 128 & 512 & 512 & 16 & 128 & $<16$ & 128 & $>256$ \\
\hline \multirow[t]{2}{*}{7} & Acute & 32 & 8 & 128 & 8 & 8 & 32 & 16 & 64 & $<16$ & $<16$ \\
\hline & Convalescent & 32 & 8 & 128 & 8 & 8 & 16 & 16 & 256 & $<16$ & $<16$ \\
\hline \multirow[t]{2}{*}{8} & Acute & 8 & 32 & $<8$ & 8 & $<8$ & $<16$ & 32 & 32 & $<16$ & $<16$ \\
\hline & Convalescent & 8 & 32 & 8 & $<8$ & $<8$ & $<16$ & 64 & 256 & $<16$ & $<16$ \\
\hline \multirow[t]{2}{*}{9} & Acute & $<8$ & 8 & $<8$ & $<8$ & $<8$ & $<16$ & 32 & $<16$ & $<16$ & $<16$ \\
\hline & Convalescent & $<8$ & 32 & $<8$ & $<8$ & $<8$ & $<16$ & $>256$ & $<16$ & $<16$ & $<16$ \\
\hline \multirow[t]{2}{*}{10} & Acute & 128 & 8 & 32 & 32 & 8 & 64 & 32 & 512 & 256 & 512 \\
\hline & Convalescent & 128 & 32 & 32 & 32 & 32 & 256 & 32 & 512 & 128 & 512 \\
\hline \multirow[t]{2}{*}{11} & Acute & 512 & 32 & 512 & 512 & 512 & $<16$ & 32 & 64 & 256 & 16 \\
\hline & Convalescent & 512 & 32 & 512 & 512 & 512 & $<16$ & 32 & 64 & 256 & 32 \\
\hline \multirow[t]{2}{*}{12} & Acute & 128 & 128 & 128 & 32 & 32 & $<16$ & 256 & 16 & 64 & 512 \\
\hline & Convalescent & 128 & 128 & 32 & 32 & 32 & $<16$ & 256 & 32 & 128 & 512 \\
\hline \multirow[t]{2}{*}{13} & Acute & 32 & 32 & 32 & $<8$ & $<8$ & 256 & $<16$ & 16 & $<16$ & $<16$ \\
\hline & Convalescent & 32 & 32 & 32 & 8 & 8 & 512 & $<16$ & $<16$ & $<16$ & $<16$ \\
\hline \multirow[t]{2}{*}{14} & Acute & 32 & 32 & 128 & 32 & 128 & $<16$ & $<16$ & $<16$ & $<16$ & $<16$ \\
\hline & Convalescent & 32 & 32 & 128 & 32 & 128 & $<16$ & $<16$ & $<16$ & $<16$ & $<16$ \\
\hline \multirow[t]{2}{*}{15} & Acute & 512 & 128 & 32 & 512 & 128 & $<16$ & 128 & $<16$ & $<16$ & 64 \\
\hline & Convalescent & 512 & 512 & 32 & 128 & 512 & $<16$ & 128 & $<16$ & $<16$ & 64 \\
\hline \multirow[t]{2}{*}{16} & Acute & 32 & 32 & 8 & 32 & 32 & $<16$ & $<16$ & $<16$ & $<16$ & 32 \\
\hline & Convalescent & 32 & 32 & $<8$ & 32 & 32 & $<16$ & $<16$ & $<16$ & $<16$ & 16 \\
\hline \multirow[t]{2}{*}{17} & Acute & 8 & 32 & 128 & 32 & 32 & $<16$ & 64 & 256 & $<16$ & $<16$ \\
\hline & Convalescent & 32 & 128 & 128 & 32 & 32 & $<16$ & 64 & 128 & $<16$ & $<16$ \\
\hline \multirow[t]{2}{*}{18} & Acute & 32 & 8 & 128 & $<8$ & 8 & $<16$ & $<16$ & $<16$ & $<16$ & $<16$ \\
\hline & Convalescent & 32 & 32 & 32 & 8 & 8 & $<16$ & $<16$ & $<16$ & $<16$ & $<16$ \\
\hline 19 & Acute & 32 & 32 & 8 & 128 & 128 & 64 & $<16$ & $<16$ & 64 & 128 \\
\hline & Convalescent & 128 & 32 & 32 & 128 & 128 & 32 & $<16$ & $<16$ & 64 & 128 \\
\hline 20 & Acute & $<8$ & 8 & 8 & $<8$ & $<8$ & $<16$ & $<16$ & $<16$ & 16 & $<16$ \\
\hline & Convalescent & 8 & $<8$ & 8 & $<8$ & 32 & $<16$ & $<16$ & $<16$ & 32 & $<16$ \\
\hline
\end{tabular}

Table Reciprocals of titres on 20 pairs of acute and convalescent sera tested by fluorescent-antibody and neutralization techniques for antibody to coxsackie $B$ viruses types $1-5$ 
By neutralization, where a four-fold rise is acceptable, 10 pairs of sera showed significant rises between the acute and convalescent sera. Seven were to one viral type only and three were to more than one viral type. By fluorescence, five of the same 10 pairs showed 16-fold or more rises, but none of these were to a single viral type.

In a series of duplicate tesis on paired sera against single viral types by fluorescence over half the duplicates showed a four-fold rise or fall on one occasion and not on the other. No significance therefore can be attached to the changes less than 16-fold which occurred in the 10 pairs of sera showing no rise by neutralization.

Three of the five pairs of sera that showed no rise by fluorescence but a rise by neutralization had initial fluorescent titres of more than $1: 32$ to the type involved, while of the five pairs that showed rises by both methods none had a titre of more than $1: 32$ by fluorescence.

Results on the paired sera with no significant rise either by fluorescence or neutralization showed 63 of the possible 100 titres to be less than $1: 16$ by neutralization. By fluorescence 41 of these 63 titres were $1: 32$ or more.

\section{Discussion}

A major disadvantage of the fluorescent antibody technique, at least using this system, would seem to be the subjective nature of the test giving rise to variability in results, and limiting the sensitivity of the test by necessitating large differences for significance. Thus, half the rises present by neutralization were missed by fluorescence. Fluorescence is also less specific, as rises when present were to more than one virus.

When there was no evidence of infection, positive titres were commoner by fluorescence than by neutralization. This could be either because fluorescence demonstrates a heterotypic response as suggested by multiple rises following infection, or that antibody stimulated by previous infections lasts a longer time than neutralizing antibody.

The presence of heterotypic antibody masking the detection of homotypic antibody could be another reason for loss of sensitivity. It is noted that rises by fluorescence tended to occur in sera with lower initial titres.

An important use of fluorescence could in theory be the demonstration of virus specific antibody in the $\gamma \mathrm{M}$ fraction of serum. Our results have not been encouraging. Six patients with and five without rises by neutralization were negative or inconclusive by this method.

The fluorescent antibody technique therefore does not appear to offer any advantage over neutralization either in information gained or sensitivity. Neither had it any compensation in the simplicity of the test although results could be available more quickly.

We are grateful to the Joint Standing Research Committee of St Mary's Hospital, W2, and to the British Heart Foundation for funds which supported this work, and to Professor Dumbell for his help and advice.

\section{References}

French, M. L., Schmidt, N. J., Emmons, R. W., and Lennette, E. H. (1972). Immunofluorescence staining of Group B coxsackie viruses. Appl. Microbiol., 23, 54-61.

Kriel, R. L., Wulff, H., and Chin, T. D. Y. (1969). Microneutralisation test for determination of rhinovirus and coxsackievinus A antibody in human diploid cells. Appl. Microbiol., 17, 611-613.

Riggs, J. L., and Brown, G. C. (1962). Application of direct and indirect immunofluorescence for identification of enteroviruses and titrating their antibodies. Proc. Soc. exp. biol. (N.Y.), 110, 833-837.

Shaw, E. D. A., Newton, A., Powell, A. W., and Friday, C. J. (1961). Fluorescent antigen-antibody reactions in coxsackie and ECHO enteroviruses. Virology, 15, 208-210. 